\title{
Optimisation of the conservation of rare and vulnerable plant species in the perspective of climate change in Lithuanian (nature) reserves
}

\author{
Gytautas Ignatavicius*, Monika Toleikiene
}

Vilnius University

*Corresponding author's e-mail: gytautas.ignatavicius@gf.vu.It

\begin{abstract}
Keywords: biodiversity, species sensitivity to climate change, factors important to species protection, protection intensity.
\end{abstract}

\begin{abstract}
Nature reserves are one of the most important measures in saving biodiversity, however, during the climate change, a real danger arises, that these territories would not be able to fulfill the objectives. In order to mitigate negative effects of climate change in protected areas it is necessary to create and apply management programs, based on future ecosystems needs. The main aim of presented study was to evaluate sensitivity of rare and vulnerable species to climate change in order to suggest measures for better management of nature reserves in the future.

According to scientific literature, 12 biological and ecological plant characteristics determining sensitivity of species (limiting factors) have been detected. 73 plant species that are protected in Lithuanian reserves were evaluated qualitatively according to limiting factors of climate change. As the result, it was offered to apply additional protection measures to 47 species in the light of climate change. Groups of plant species that should be affected highly negatively or highly positively were identified. $16 \%$ of plant species protected in nature reserves were evaluated as very sensitive to climate change and the condition of these plants may worsen. On the other hand, 14 plant species were given as least sensitive to negative effects and future climate is more favorable to species growth and spread than the existing. The highest danger is predicted for Silene chlorantha (Willd.) Ehrh., and the best condition is predicted for Mentha longifolia (L.) Huds. Dactylorhiza incarnata (L.) Soó.

The study also gives recommendations for the protection of rare plants in the future. Different management measures are taken into account: mitigation of the direct effect of climate change (I), improvement of an existing level of rareness (II), respecting the relation to physical and biological environment (III), consideration of spread and geographical limits (IV). Three management intensity levels were suggested according to species sensitivity.
\end{abstract}

\section{Introduction}

\section{Climate change in protected areas}

Even though possible causes of climate change are still debated, the fact of the climate change itself is evident and undisputed. Having regard to tendencies of climate change of past 200 years, during the $21^{\text {st }}$ century a rapid temperature growth during winter season (from November to March) is predicted. According to different RCP scenarios winter temperature until 2100 will grow from 2 to $4^{\circ} \mathrm{C}$ in Lithuania while summer temperature will grow accordingly from 1.5 to $4^{\circ} \mathrm{C}$ (IPCC 2013). The rainfall of winter season might change in the interval $0-20 \%$. Summer rainfall is unclear - some models predict insignificant (up to 10\%) drop in rainfall while others show insignificant increase (IPCC 2013). In addition to those climate change indices scientists warn that extreme natural events can go worse. Floods and storms (especially in winter season) are already one of the major threats in countries of the Baltic Sea region. Rise of sea level and often stronger natural disasters are predicted as well (Povilaitis et al. 2009). It was already noticed that in years 1961-2010 the duration of snow cover has shortened by 17 days in Lithuania while maximum thickness of snow cover has lowered by $3.5 \mathrm{~cm}$ (Gečaite and Rimkus 2010). In recent decades of the $20^{\text {th }} \mathrm{c}$. due to climate change frost starts melting earlier and frost duration has shortened by approximately two weeks. Defrost process happens 1-2 times (sometimes up to 7), compared to previous years when frost continued for whole season (Taminskas et al. 2005).

National reserves cover 3\% of protected areas in Lithuania. Natural reserves are used to protect marshy complexes. In 1993 they became a part of the Ramsar Convention list of wetlands of international importance. There are three national strict natural reserves in Lithuania: Čepkeliai, Kamanos and Viešvilè. The weather combines temperate oceanic and continental climate and there are 10 habitats of the European Community interest. Čepkeliai reserve covers 11,227 ha of the territory, while buffer zone covers 1,572 ha of the territory; there are 59 rare 
plant species. Kamanos reserve covers the territory of 3,961 ha (buffer zone of 2,530 ha), there are 47 rare plant species. Viešvilè reserve covers the territory of 3,220 ha, there are 50 rare plant species.

The experience shows the great influence of global climate anomalies on the condition of marsh ecosystems and their distribution. Changing climate changes the specific composition of wetland phytocenosis. Extreme droughts and floods may disrupt natural hydrological cycle. During research in the last decades of the 20th century in Čepkeliai swamp, a rapid forestation was noticed as well as the main reason of rapid succession of swamp flora was found to be global climate changes or recurring climate fluctuation. The hypothesis that the changes of water balance were influenced by intensive human activity in swamp and around was denied (Taminskas et al. 2008). However, Lithuanian experience shows that the restoration of raised bogs plant communities is possible. In 2011 an experiment of restoration of raised bogs plant communities was started in decommissioned part of Aukštumala peatland in which $94 \%$ of all donor plant cover fragments grew.

\section{Climate change influence on species and ecosystems}

In the last century the influence of climate change which is seen as phenological, demographical and spatial shift is noticed in many organism taxon cases (Ackerly et al. 2010). Influence of climate change on natural ecosystems may cause changes of several types (Ozolinčius et al. 2013). Due to temperature and rainfall differences the distribution of ecosystems will change, first of all, shifting existing boundaries between ecosystems. When ecosystems shift in space, their structure and diversity will change as well (Davis and Shaw 2001). Climate change also alters ecosystem phenology, processes of inheritance and dynamics of community (Campbell et al. 2009). Scientists agree that one effect causes others, therefore, it is very difficult to determine the scale of change. On the first level, climate change will cause disappearance of species, migration, shift and loss of genetic diversity, invasion and adaptations (Bertin 2008). On the second level, the behavior of species will be affected as well as survival rate and interrelationship. Affected populations will change the "interaction web" on the whole community level (Gilman et al. 2010, Walter 2010).

Further response of biodiversity to climate change may occur through several mechanisms. One of them is ability of organism to adapt to new conditions through unusual morphological, physiological and behavior alternation. Some scientists claim that species would not be able to adapt to climate change (Lavergne et al. 2010). However, there is an opinion that selection based on quick evolution and plasticity (in extreme conditions) is possible and even proved by experiments (Bell and Gonzalez 2009). Otherwise the response of species to climate change may occur through the shift of its climate niche to three axes: time, space and individual (Bellard et al. 2012). If species were not able to adapt or move along the shift direction, its extinction would be predicted. In the future extinction may both hit individual species and cause cascading catastrophic extinction - 'the extinction chain' (Brook et al. 2008). However, the response of flora to climate change relies on a group of characteristics, namely, species of plant, genetic features of the breed, the features of local soil, water mode, mineral food substances, the quality of air and interaction of adaptation processes (Povilaitis et al. 2009).

\section{Influence of climate change on protected areas}

A number of predictions about climate change effect towards protected territories based on past and present experience is growing. Researches conducted in California and Nevada show that up to 2100 , due to changing climatic conditions, the territory of many protected areas will become smaller. A new climate regime will reduce the favorable conditions for protected ecosystems and expand heterogeneity of the landscape (Ackerly et al. 2010). $75-80 \%$ of national parks will experience shift of dominant flora when the level of $\mathrm{CO}_{2}$ is doubled (Hannah et al. 2000). Research covering 1200 European protected species of flora showed that in 50 years $6-11 \%$ of flora species from protected areas will potentially go extinct. Also, in a landscape view it is modeled that when climate conditions shift, $5 \%$ of species will lose their climatic niche, $2 \%$ will have non-overlapping actual and potential distribution (compared to future 50 years) and $93 \%$ of species will maintain the overlapping distribution of different scale (Araujo et al. 2004). Lithuania is expected to lose part of plants and a danger of non-overlapping species distribution in 50 years is predicted too. In order to save representative national plant species up to 2050 , a territory of $3,350 \mathrm{~km}^{2}$ of protected territory should be added only in Western Europe (Hannah et al. 2007).

\section{Management measures of protected areas for adaptation to climate change}

Nowadays there are more than 100,000 protected territories in the world covering $12 \%$ of the total land area. However, many of them have been founded in the last 20 years, so the type of protection and the quality is inadequate to future needs (Barber et al. 2004). The factor of climate change is not integrated in the selection of protected areas, but having enough proof on the influence of climate change the selection technique of protected areas have to guarantee long lasting survival of protected species (Araujo 2004). Decisions for climate change management should have clear goals, action plan, a model showing the influence of actions to overcome the problem, and value of optimizing showing the best measure to reach the goal (Conroy et al. 2011).

Scientists prove that the influence of climate change is undoubted and should become more intensive in the next 50-150 years. Management plans of protected areas are usually prepared for a period of 3-10 years, while the minimum appropriate climate change management plan should be for 30-50 years, and a period of 100 years would cover all possible effects of climate change (Hannah et al. 2002). Future predictions were started to be used more widely: scientists' and managing division's warnings about future risks, showing the relation of climate change and biological change, supporting the development of the public strategies and initiatives, and trying to reduce climate change effect on biological diversity (Bellard et al. 2012).

Management of climate change in protected territories might be adapted on different levels, i.e., regional level (e.g. Europe, Baltic States), national level (e.g. changing the structure of Lithuanian protected areas management), local level - in the case of separate protected areas (e.g. specific 
action plan of reserve management). Scientists claim that changes are necessary on all of these levels. Regional climate change management: Climate change is a global process where country borders do not apply, therefore, in the beginning active regional cooperation is needed. IUCN recommends institutional changes on three levels which would reflect management of protected territories in changing climate and environment. First of all, global protection standard should be moved to local level and global cooperation would ensure the effectiveness of decisions. Furthermore, new institutions and systems of governance are needed (called third power). Thirdly, globalization of communication, knowledge and culture (Barber et al. 2004). National decisions on climate change management may be enforced through institutional action plan adaptation to future situation and setting new goals in protected territories. In 2009 Hansen et al. presented „Climate-smart conservation strategy“. They claim that during the climate change four main concepts should be recognized, i.e., to conserve adequate and appropriate space, reduce non-climatic stress, use adaptive management and test strategies adapted to climate change beforehand, and therefore reduce the speed of climate change and amount reducing overall risk (Hansen et al. 2009). Local climate change management: Since protected areas are of different format and habitats, there are different communities and species conserved, the effect of climate change might occur inequitably. Every protected territory should determine exposed objects and evaluate the effect of climate change individually. If rare species move from protected territory then species representativeness degree should be ensured by adding territory or survival of species can be guaranteed by founding territories where species could comfortably set in a disperse way. Species with low adaptive ability, the highest vulnerability and sensitivity need the most intensive protection measures (such as conservation ex-situ and revival) (Dawson et al. 2011).

Many articles with recommendations on how to integrate climate change factor to biodiversity management process were published in the last decades. Recommendations and strategies were created both for individual population and ecosystems to manage them properly (Heller and Zavaleta 2009). However, in management program of Lithuanian protected territories there is no future control of the effects of climate change. Therefore, according to recommendations management plans should be changed and adapted to future perspectives.

\section{Materials and methods}

\section{Study area}

Three Lithuanian national strict nature reserves: Čepkeliai, Kamanos and Viešvile have been investigated in our study (Fig. 1). Study object is 73 rare flora species conserved in those reserves. Two rare species are protected in Lithuanian national strict nature reserves that belong to Lycopodiophyta division, three that belong to Polypodiophyta and 68 belonging to Magnoliophyta division.

\section{Indicators and data}

Since projections for plants condition in the future should be predicted, it is essential to describe possible change of climate conditions in the future. The period was chosen up to the year 2100 . This period is often used by scientists as the most favorable to model all effects of climate change because of effect-response speed differences among ecosystems. We chose climate change data for different Lithuanian cities modeled by Vilnius University (Lithuania) meteorological station employees: total monthly precipitation ( $\mathrm{mm} / \mathrm{month})$ and average monthly temperature $\left(\mathrm{C}^{\circ}\right)$. To describe some parameters of climate ECHAM5 forecast model based on A1B greenhouse gas emission scenario was used. According to it, the average annual yearly temperature will rise about $4^{\circ} \mathrm{C}$ in all Lithuania strict nature reserves (comparing 2000-2010 and 2090-2100 years periods). Although winter average temperature will rise about $5.1^{\circ} \mathrm{C}$ (from -2.36 to $\left.2.74^{\circ} \mathrm{C}\right)$.

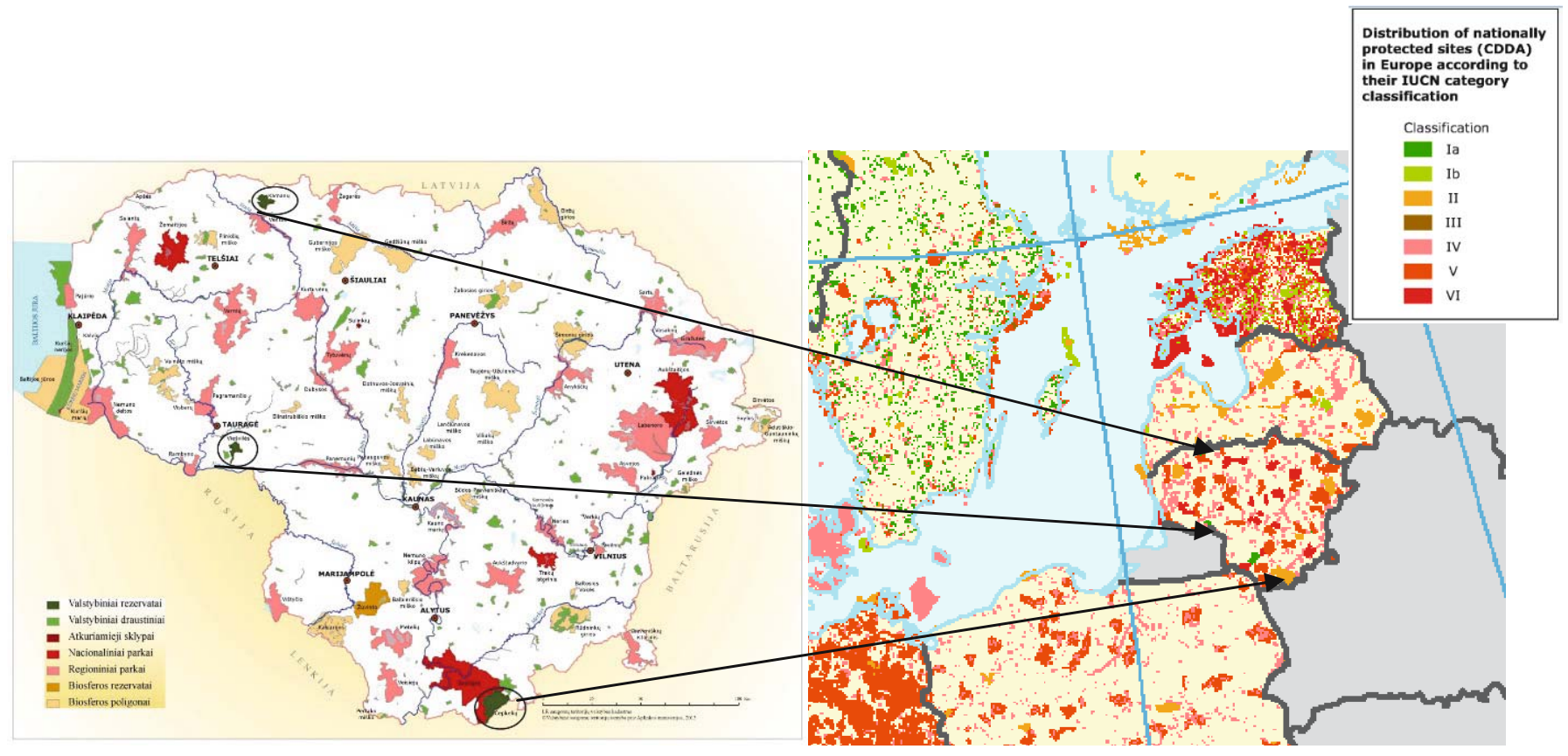

Fig. 1. Lithuanian natural protected areas evaluated in research 
At first step, the sensitivity of protected plants to climate change was evaluated. Having reviewed scientific literature, the list of ecological and biological plant features describing the sensitivity of species to climate change and reaction mechanisms was made. These features describing species response to climate change were divided into three types and called 'limiting factors' (Table 1). 12 factors affecting the development of plant population in Lithuania through climate change were identified.

Further in the article they are given under Roman numerals and their evaluation method is detailed according to these features. Plant features were evaluated by points $+1 ; 0 ;-1$. Characteristics that could improve plant condition during the climate change were evaluated positively $(+1)$. Characteristics that would not affect (improve or worsen) plant condition were evaluated neutrally (0). Characteristics that would limit plant widespread, movement and survival opportunities after climate change were evaluated negatively (-1). All research plants from three reserves were evaluated in this system. Rare plant features and reaction mechanisms were identified according to many scientific articles and various databases: "The Euro+Med PlantBase"; "United States Department of Agriculture. Natural Resources Conservation Service. Plant Database"; "Catalogue of Life"; "Online Atlas of British and Irish flora", "Flora Europaea"; "E-flora BC: Electronic Atlas of the Flora of British Columbia"; and "IUCN red list".

The evaluation structure of species sensitivity to climate change according to different limiting factors are as follows:

I. Tolerance of new Lithuanian climate conditions (temperature, precipitation

+1 - Climate conditions are in favor of species growth

0 - Climate condition change does not affect or slightly changes distribution

-1 - Climate conditions are disadvantaged

II. Ability to adapt to changing climate conditions:

+1 - The species is adaptive, tolerates wide range of climate conditions, extremities

0 - Average adaptability of the species; sensitivity to extreme conditions, drought

-1 - The species is not adaptive; sensitive to minor deviations from exact conditions; tolerates narrow range of climate conditions

III. The importance of frost and snow cover:

+1 - The species is residential to conditions of recurring frost and changing snow cover, but is not dependent on them; the exact period and conditions of overwintering is not necessary; may not overwinter

0 - The species may survive recurring frost, but only small amount of it

-1 - A long frost period or snow cover is necessary to species survival; exact overwintering period is necessary; does not survive extreme, changing conditions

IV. Hydrological regime:

+1 - A wide range of hydrological conditions is acceptable

0 - A plant is not dependent on exact hydrological regime, but tolerates either drought or wet conditions; goes extinct after changing hydro regime radically or drying the habitats

-1 - A species is sensitive to changes of hydrological regime; dependent on exact hydrological regime.

V. The situation of Lithuanian populations (in species distribution area zone);

+1 - The species is in the northern zone of distribution area or near it

0 - The species is found in whole Europe or in a bigger part of it; Lithuania is in the middle of the area

-1 - he species is in southern zone of distribution area or near it; distribution area of species in Europe is small

VI. Climate needed for growing and widespread:

+1 - The species grows in both oceanic and Continental climate conditions; in Lithuanian climate conditions as well

0 - The species is sub-oceanic or sub-continental, avoids some climate conditions uncharacteristic for Lithuania

-1 - the species grows only in oceanic climate conditions; grows only in continental climate conditions

VI. Landscape peculiarities and limitations of species distribution:

+1 - The species grows both in plains (lowlands) and mountains; grows in lowlands and in conditions typical for Lithuania and reserves

0 - The species grows in conditions of Lithuanian landscape, but is not widely spread; does not grow in Lithuanian lowlands; does not show exact widespread boundaries

-1 - The species usually grows in the mountains; or in conditions that are unlikely for Lithuania, does not like slopes, is limited

Table 1. Plant features determining specie sensitivity to climate change

\begin{tabular}{|c|c|c|}
\hline \multicolumn{3}{|c|}{ Plant features determining specie sensitivity to climate change } \\
\hline \multirow{2}{*}{$\begin{array}{l}\text { Features affected by climate change } \\
\text { directly }\end{array}$} & \multicolumn{2}{|c|}{ Features affected by climate change indirectly: } \\
\hline & $\begin{array}{l}\text { Defining the spread through displacement } \\
\text { opportunity (geographically) }\end{array}$ & $\begin{array}{l}\text { Defining the spread through relation } \\
\text { with environment and possible threads }\end{array}$ \\
\hline $\begin{array}{l}\text { 1. Tolerance of new Lithuanian climate } \\
\text { conditions (temperature, precipitation); } \\
\text { 2. The ability to adapt to changing } \\
\text { climate conditions; } \\
\text { 3. The importance of frost and snow } \\
\text { cover; } \\
\text { 4. Hydrological regime }\end{array}$ & $\begin{array}{l}\text { 5. The situation of Lithuanian populations } \\
\text { (in specie distribution areal zone); } \\
\text { 6. Climate needed for growing and spread; } \\
\text { 7. Landscape peculiarities and limitations } \\
\text { of specie distribution; } \\
\text { 8. Addition of specie individuals from other } \\
\text { regions after the climate change; }\end{array}$ & $\begin{array}{l}\text { 9. The level of specie spread in areal; } \\
\text { 10. The condition of the plant in } \\
\text { Lithuania; } \\
\text { 11. The amount of right habitats for } \\
\text { specie in Lithuania; } \\
\text { 12. Relationship with other community } \\
\text { members; }\end{array}$ \\
\hline
\end{tabular}


VIII. Addition of species individuals from other regions after the climate change:

+1 - Possible addition of individuals in the case of area displacement

0 - The possibility of addition of individuals in the case of displacement is average; species cannot spread alone

-1 - The possibility of addition of individuals in the case of displacement is low or impossible

IX. The level of species widespread in the area:

+1 - The species is well spread throughout the area; in many European countries is not protected

0 - The species is spread, but in some countries is protected

-1 - The species is rare in the whole area; included in the Red Book of IUNC; protected according to international regulations

$\mathrm{X}$. The condition of the plant in Lithuania:

+1 - Conserved species with recreated abundance, belonging to 5 (Rs) category

0 - Rare species belonging to $3(\mathrm{~V})$ category, species of undefined status belonging to 4 (I) category

-1 - Species going extinct or on the path to extinction - 1 (E); vulnerable species with population and number of individual rapidly decreasing $-2(\mathrm{~V})$

XI. The amount of right habitats for species in Lithuania:

+1 - Various environmental characteristics for Lithuania are appropriate to grow

0 - Appropriate habitats are found in Lithuania, but are not widely spread

-1 - The characteristics of the needed habitats are rare in Lithuania

XII. Relationship with other community members:

+1 - The composition of the community may change; species is independent; species is competitive

0 - When climate change does not affect the parts of the community; or the condition will not change

-1 - The species is very sensitive to community changes, depends on exact composition of the community; has high fidelity

After evaluating each species sensitivity level, weight scores for limiting factors were given. 'Weight score' was counted as the sum of each score given for all 73 species
$(-1 ; 0$ or +1$)$ (results are given in Fig. 4). In the second part recommendations for the change of management of protected territories in the next hundred years are given. Having analyzed the literature and identified climate change management measures offered by scientists, additional protection measures were suggested to improve the effectiveness of management of Lithuanian protected territories during the climate change. All measures were divided into four categories according to purpose: direct effect of climate change, existing level of rareness, relation to physical and biological environment, and geographical limits and limits of widespread. Protection measures applied to specific species were ascribed to certain group. The scheme of protection intensity was also prepared on the bases of the scientific literature.

\section{Results}

\section{The sensitivity to climate change of plants protected in Lithuanian natural reserves}

The evaluated plants sensitivity to climate change covered the range of scores from -6 to +9 . According to total evaluation score of sensitivity, plant species were divided into three groups. Plants in the first group were those with the score interval $[-6 ;-3]$, in the second group with the score interval $[-2 ;+2]$ and the third one with values of $[+3 ;+9]$ (Fig. 2).

$16 \%$ of evaluated plant species belong to I category. These species are very sensitive to climate change. Due to the effect of climate change the condition of plants may worsen, also species have low possibilities to spread. Special protection and management plans should be prepared for these groups and species themselves should become priority. If radical measures to protect these species are not ensured they may become extinct both in Lithuanian and European reserves. 20 plant species have average sensitivity to climate change and fall into II category. They have a balance of restrictive and adaptive features. The climate may affect the condition of these species. However, applying the right management measures could ensure that the condition of II category plant populations should change just a little and no damage will be done. Plant species that are least sensitive to negative effects of climate change belong to III category. These species are superior because of two reasons: one is that climate is not a limiting factor ( 27 species) and the rareness of

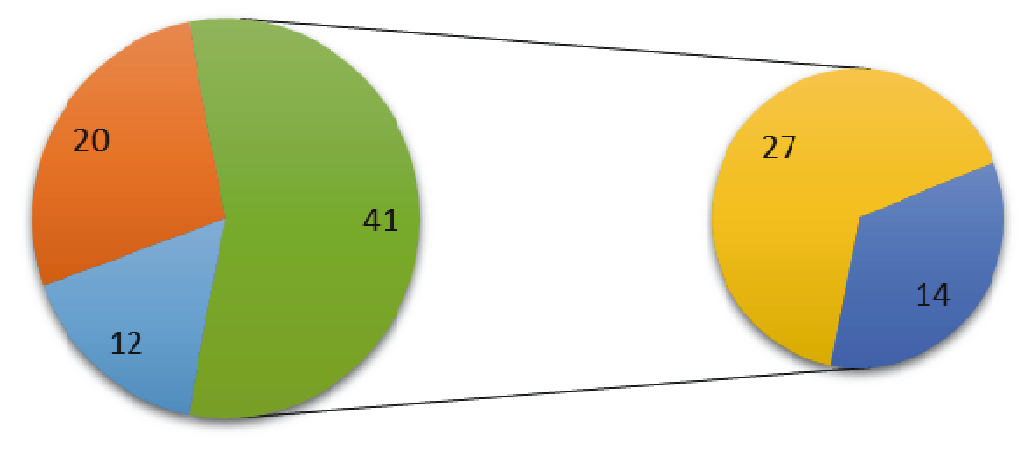

- category (from -6 to -3 )

II category (from -2 to +2 )

- III category (from +3 to +9 )

Climate change is not a limiting factor

Climate change may improve the condition

Fig. 2. The division into categories of all protected plants in reserves according to the sensitivity to climate change 
species is defined by direct anthropogenic activity; the second is that future climate is more favorable for species growth and spread than the existing (14 species). In future, plants belonging to this group should spread, the condition of their population should improve therefore, and the level of protection should decrease adaptively. During the climate change the protection of some species of III category may not be needed in the future. During the research it was noticed that the number of plants belonging to different sensitivity groups in different reserves varies. However, not all reserves that were analyzed are similar, in fact half of all analyzed plants belong to III group of sensitivity and the rest two categories make up another half.

Groups of plant species that should be affected highly negatively or highly positively were distinguished (Table 2). The highest danger is predicted for Silene chlorantha (Willd.) Ehrh., and the best condition is predicted for Mentha longifolia (L.) Huds. Dactylorhiza incarnata (L.) Soó.

In Lithuanian natural reserves, 46 plant species belonging to I and II rareness categories are protected according to order of the Minister of Environment of 2005 July 16 (No. D1-301). The hypothesis was that climate change would mostly affect the rarest species. Trying to prove it the sensitivity coefficients of the rarest plants were compared to the total sensitivity coefficient of all protected plants (Fig. 3).
The number of plants belonging to III category of sensitivity to climate change was slightly different. However, climate change will affect positively fewer plant species belonging to the rarest categories (I and II of LRB) than species that are not so rare. A negative dependency exists between the level of rareness and the amount of plants belonging to the I category of sensitivity. More plants belonging to the rarest groups of sensitivity will be affected negatively by the climate change compared to plants that are not so rare. Plant species in I and II rareness categories (of LRB) as well as I sensitivity category are in the risk zone to be the first ones that go extinct during the climate change. The following plants are in the highest risk zone: Pedicularis sceptrum-carolinum L., Carex magellanica Lam., Juncus stygius L., Listera cordata (L.) R. Br., Pulsatilla patens (L.) Mill., Dianthus arenarius L., Silene chlorantha (Willd.) Ehrh., and Betula humilis Schrank.

\section{The validity of plant characteristics evaluating the sensitivity to climate change}

Evaluation criteria had different contribution to the total score of plant sensitivity (Fig. 4). Total validity score of characteristics was between -42 to +47 . The following characteristics had the greatest negative impact on the evaluation of plant sensitivity: the climate needed to grow and spread (balance is +47 ); the

Table 2. Plant species that should be comaparatively affected by the climate change the most

\begin{tabular}{|c|l|c|l|c|}
\hline \multirow{2}{*}{ No. } & \multicolumn{2}{|c|}{ Plants of the highest negative sensitivity } & \multicolumn{2}{c|}{ Plants of the highest positive sensitivity } \\
\cline { 2 - 6 } & \multicolumn{1}{|c|}{ Specie } & Score & \multicolumn{1}{c|}{ Specie } & Score \\
\hline 1. & Silene chlorantha (Willd.) Ehrh. & -6 & Mentha longifolia (L.) Huds. & +9 \\
\hline 2. & Juncus stygius L. & -5 & Dactylorhiza incarnata (L.) Soó. & +9 \\
\hline 3. & Pulsatilla patens (L.) Mill. & -5 & Hedera helix L. & +8 \\
\hline 4. & Listera cordata (L.) R. Br. & -4 & Polemonium caeruleum L. & +8 \\
\hline 5. & Tragopogon gorskianus Rchb. f. & -4 & Campanula cervicaria L. & +8 \\
\hline 6. & Silene lithuanica Zapał. & -4 & Agrimonia procera Wallr. & +8 \\
\hline 7. & Dactylorhiza longifolia (Neuman) Aver & -4 & Trifolium lupinaster $L$. & +8 \\
\hline
\end{tabular}

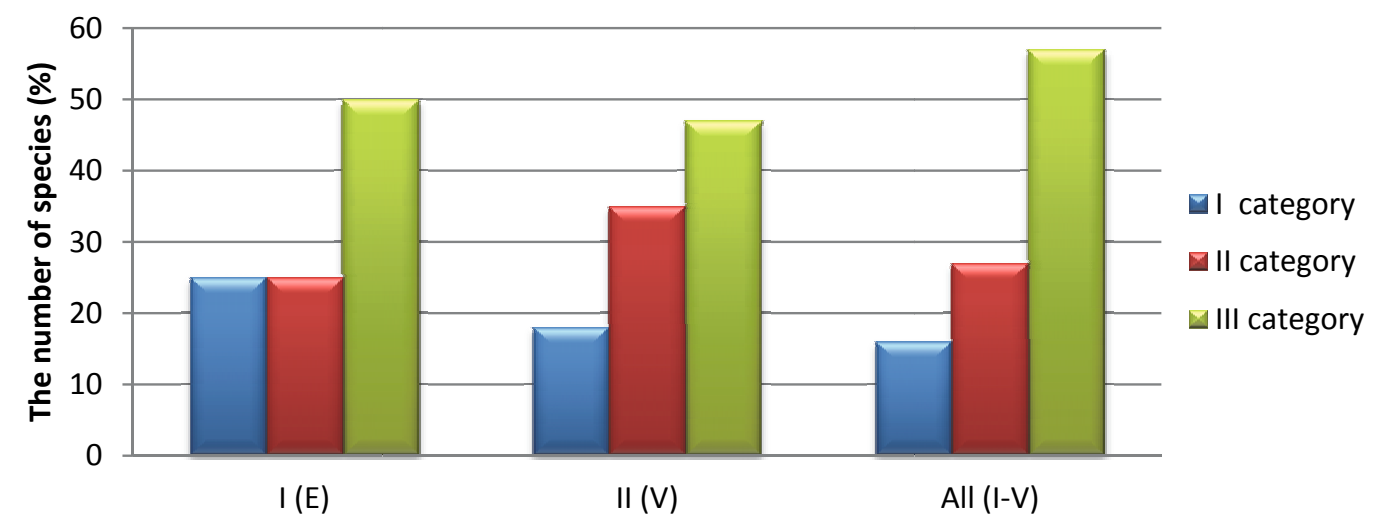

Fig. 3. The sensitivity to climate change dependency on the level of rareness 
landscape peculiarities of plant widespread, limits $(+38)$; addition of individuals from other regions after the climate change $(+32)$. According to this, we can claim that geographical peculiarities of species widespread and distribution are rarely a limiting factor even evaluating climate change effects on plants. These factors gave the superiority to the most species against restricted distribution plant species.

Only three factors (criteria) had negative value towards all plants: the condition of plant species in Lithuania (balance $-42)$; the level of species widespread in the area (-6) and hydrological regime (-6). All investigated plants were rare and protected, but negative "the condition of plant species in Lithuania" balance of scores shows that plants of I and II categories form the biggest part in reserves. Also, the level of species widespread in the area shows that more plant species were rare in the whole area. A great part of protected plants are sensitive to hydrological regime - another factor. All other factors had positive effect on plant sensitivity, which shows that many plants are similar in evaluating the system of these criteria. However, this method helps to distinguish a part of plants for which those factors show the increased sensitivity to climate change. According to every limiting factor negative score (-1) highest risks can be predicted for plants in different reserves; particular attention should be given to those risks in management programs (Fig. 5).

In the first group of factors which is related to direct climate change (I, II, III, IV) we see that the rise of temperature is unfavorable for $27 \%$ of plants, while the change of hydrological regime is unfavorable for $46 \%$. Another group (V, VI, VII, and VIII) is related to indirect effect of climate change through ability to spread had similar limiting action. The usual factor limiting plants was the climatic adaptation of plants to exclusively continental or exclusively oceanic climate. The third factor group (IX, X, XI, XII) is related to indirect effect of climate change through relation to environment and other dangers and limiting factors having an impact on plant survival. It was identified that when species belong to I and II rareness categories $(58 \%$ of the analyzed plant species in

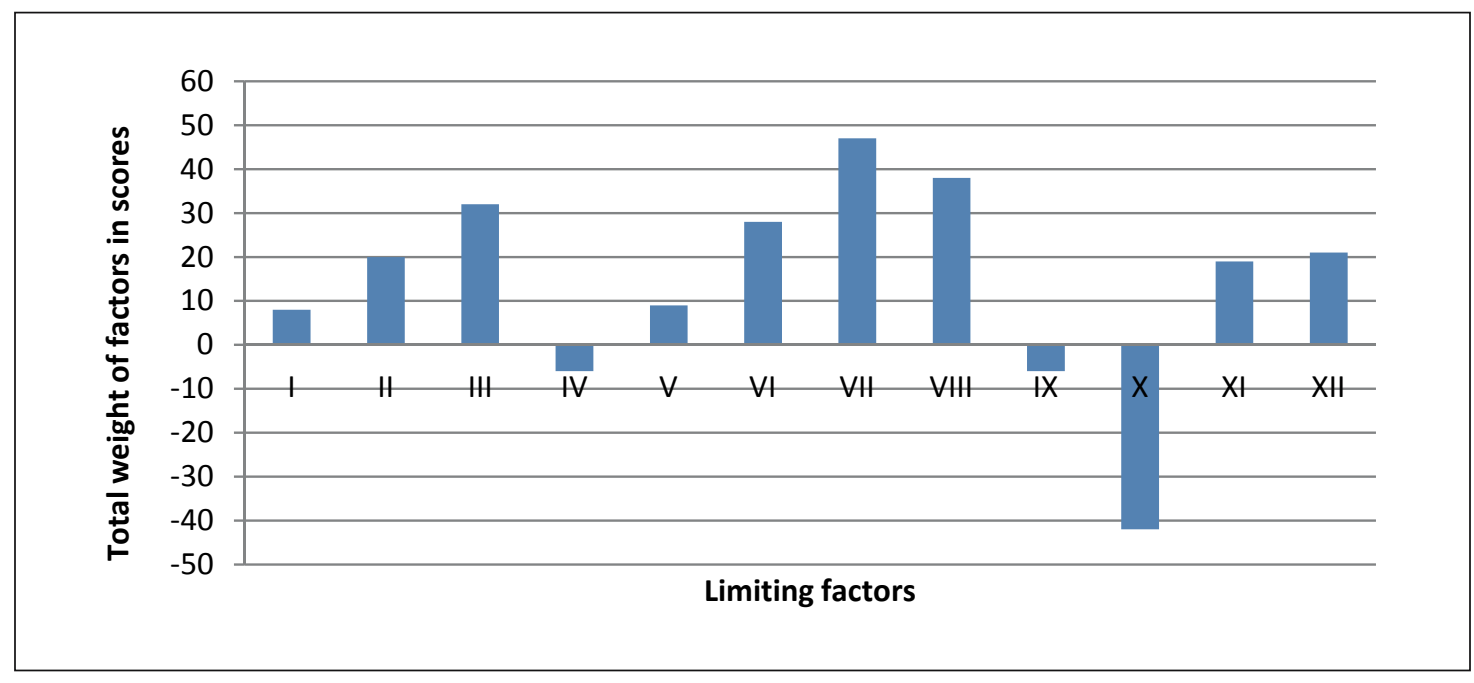

Fig. 4. The weight scores of evaluation criteria (limiting factors)

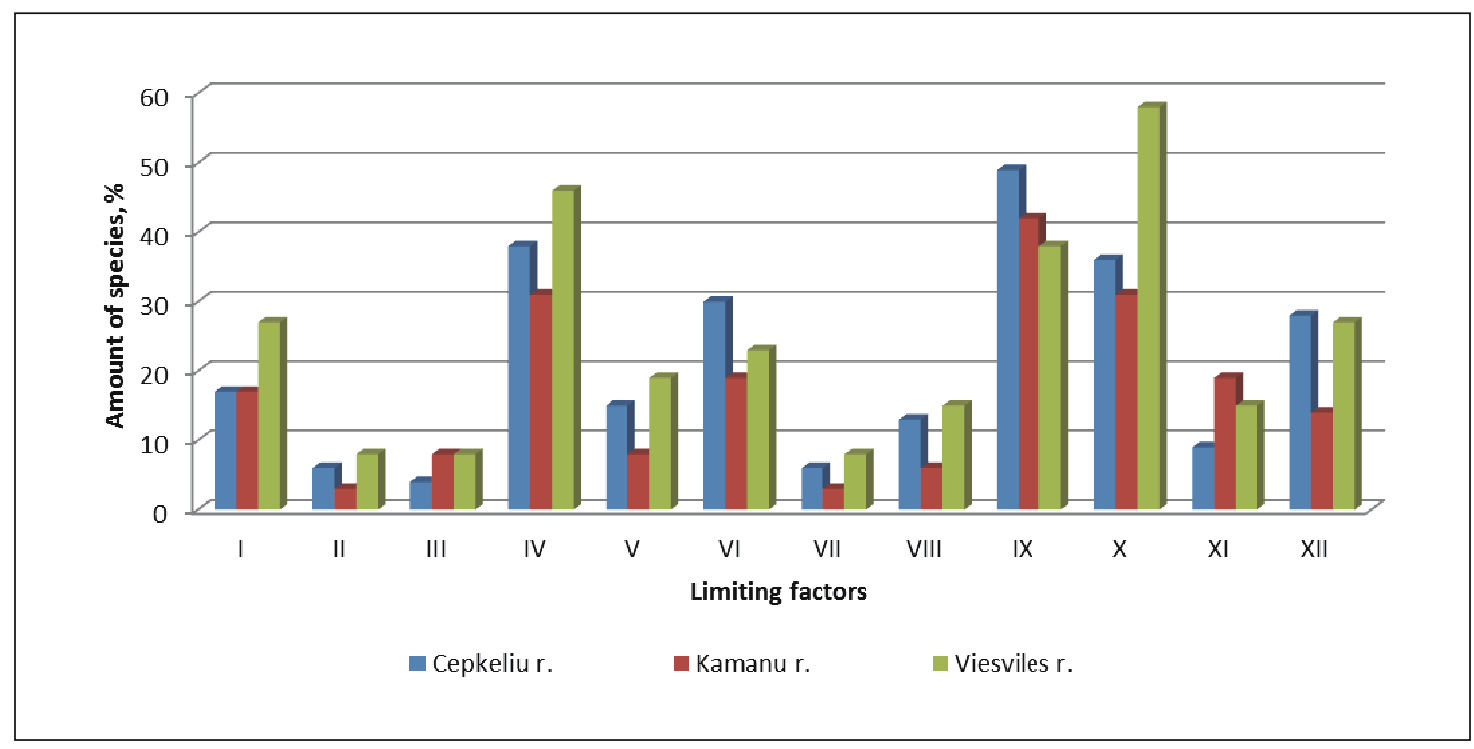

Fig. 5. A part of protected plants in different reserves affected by different limiting factors 
Viešvilè reserve) and the condition of population is poor even in good climate conditions species hardly recover. Also, more vulnerable species are more sensitive to any environmental and climate changes. The most limiting factor in Čepkeliai and Kamanos reserves is the level of species widespread in the area. It shows that, respectively, $49 \%$ and $42 \%$ of plant species protected in those reserves are rare in the whole area of spread and protected plant species in whole Europe as well.

\section{Protection measures of rare plants in reserve during climate change}

In the second part of the research it became clear that not all plants are equally sensitive to climate change. For some plants climate change is a strongly limiting factor while others are not affected by climate change; the rareness of species depends on direct anthropogenic effect, and third part of plants is stimulated by the climate change. Due to these reasons species protection measures should be different and modified according to characteristics of every species in the future. All investigated species can be divided into groups according to factors of climate change effect (Fig. 6).

When factors are not typical (b, e, h, l cases) additional protection measures are not needed. However, attention should be given to mitigate dangers unrelated to climate change (e.g. destruction of habitats, draining, overgrazing, gathering, pollution).

During the research it was identified that protection measures of three types should be applied for even 50\% of plant species belonging to the I category of sensitivity to climate change in Lithuanian natural reserves. To manage the other half two types of proper protection measures should be applied. The measures of the control of the rareness level should be applied to the most (92\%) plant species from this category of sensitivity level.

Managing climate change effect on plants in the future it is important not only to predict additional measure but also to choose the right intensity. Species were divided into three categories according to sensitivity to climate change. According

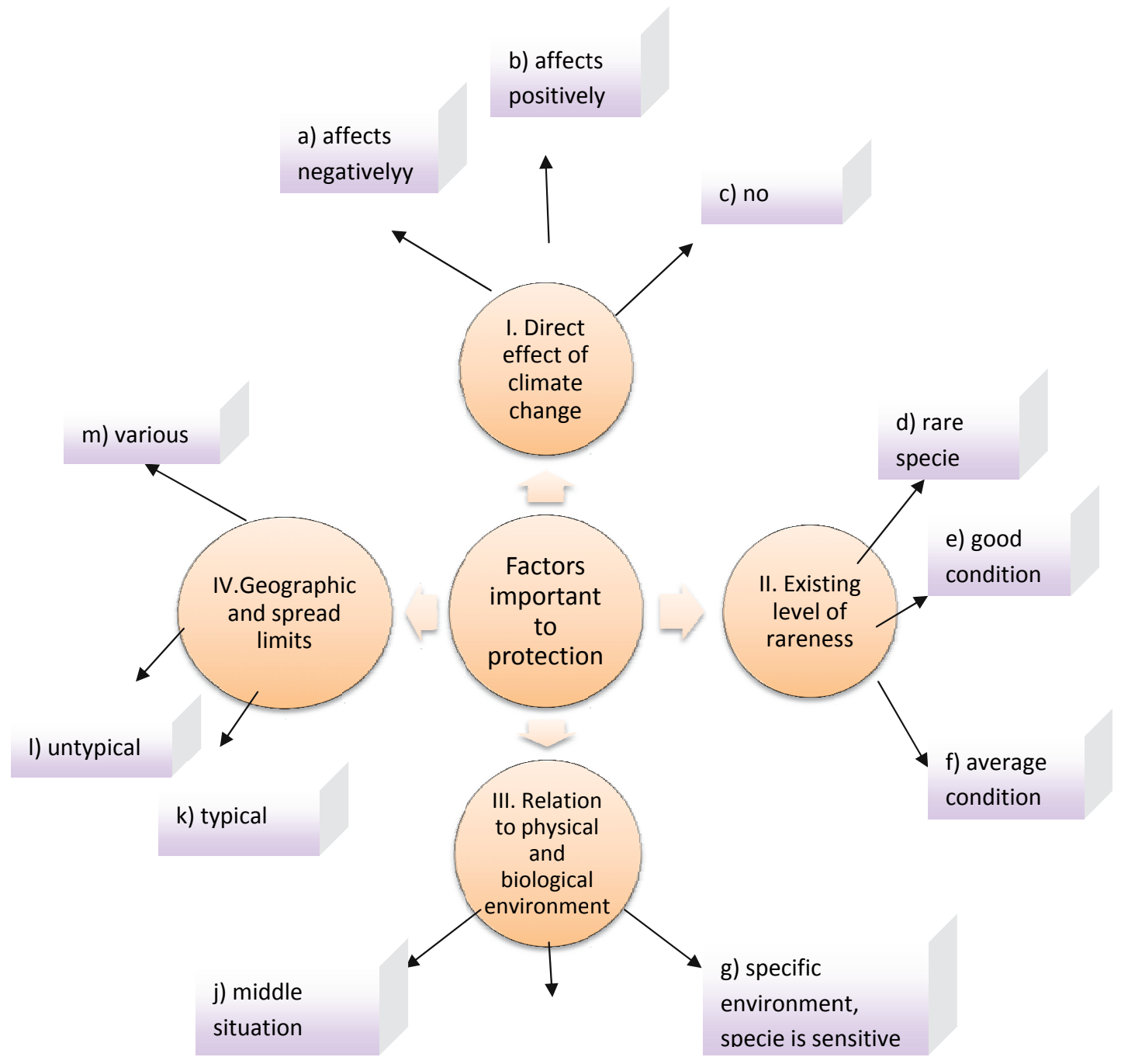

h) various

environment, specie

is insensitive

Fig. 6. The identification scheme of factors important to species protection 
Table 3. Management measures of climate change effect on species

\section{The direct effect of climate change - a) negative}

To conserve genetic divergence (Chambers et al. 2005); to protect species ,ex-situ“ (Dawson et al. 2011); to protect inicator species (Noss 2001); to study physiological, behaviour and demographic response to climate change (Dawson et al. 2011, Williams 2000); to intensify monitoring (McMahon et al. 2011); to model future responses (Ackerly et al. 2010, Hannah et al. 2000); to use foresight models to detect new protected areas (Hannah et al. 2007); to integrate climate change by planning tasks (Araujo et al. 2004); to reset protection objectives (Scott et al. 2002).

\section{Existing level of rareness $-\mathrm{d}$ ) specie is rare}

To widen genetic diversity of species restoring territories and planting forests (Lovejoy and Hannah 2005); to mitigate other stresses (Hansen et al. 2009); to protect metropopulations (Opdam et. al. 2004); to improve restoring technologies (Millar et al. 2007); to identify indicator species (Chambers et al. 2005); to experiment with refugia (Millar et al. 2007); to protect the coeficient of representative species (Hannah et al. 2007); To concentrate the protection to communities that are most sensitive to climate changes (Mawdsley et al. 2009); to start adapted strategic agriculture (Noss 2001).

\section{Relation to physical and biological environment - g) specific environment, specie is sensitive}

To mitigate other stresses (Hansen et al. 2009); recover extinct habitats (Lawler 2009); to controll grazing and to change field labour schedules (Chambers et al. 2005); to improve the protection of swamps (Hartig et al. 1997); to identify adaptive genes (Rice and Emery 2003); to predict effects on ecosystems (Bellard et al. 2012); to protect all parts of biodiversity (Pyke and Fischer 2005); to extend the surface and amount of protected territories (Midgley et al. 2002); to create buffer zones, to preserve heterogenity of the environment; to control the spread of the forest (Millar et al. 2007).

\section{Spread and geographical limits - k) typical}

To improve regional coordination (Soto 2001), cooperation (Barber et al. 2004); resource sharing (Hannah et al. 2000); to move species (Mawdsley et al. 2009); better to protect many small territories than one big territory (Pearson, Dawson, 2005); o study disperse abilities of species, migration, gene flowing (Rice and Emery 2003); restore the movement of species in space in different historic periods (McMahon et al. 2011); to improve consolidation of territories (Williams 2000); to establish corridors (Lawler 2009); to protect the boundaries (Welch 2005); to establish longitudinal linear protected areas (Pearson and Dawson 2005); to ensure disperse possibilities (Midgley et al. 2002) to adjust space according to shift of habitats (Bellard et al. 2012); to establish reserves by the northern boundary of the specie spread (Shafer 1999).

Dactylorhiza longifolia (Neuman) Aver.

Silene lithuanica Zapał

Tragopogon gorskianus Rchb. f.

Betula humilis Schrank

Silene chlorantha (Willd.) Ehrh

Dianthus arenarius L

Pulsatilla patens (L.) Mill.

Dactylorhiza traunsteineri (Saut.) Soó.

Listera cordata (L.) R. Br.

Juncus stygius L.

Carex magellanica Lam.

Pedicularis sceptrum-carolinum L.

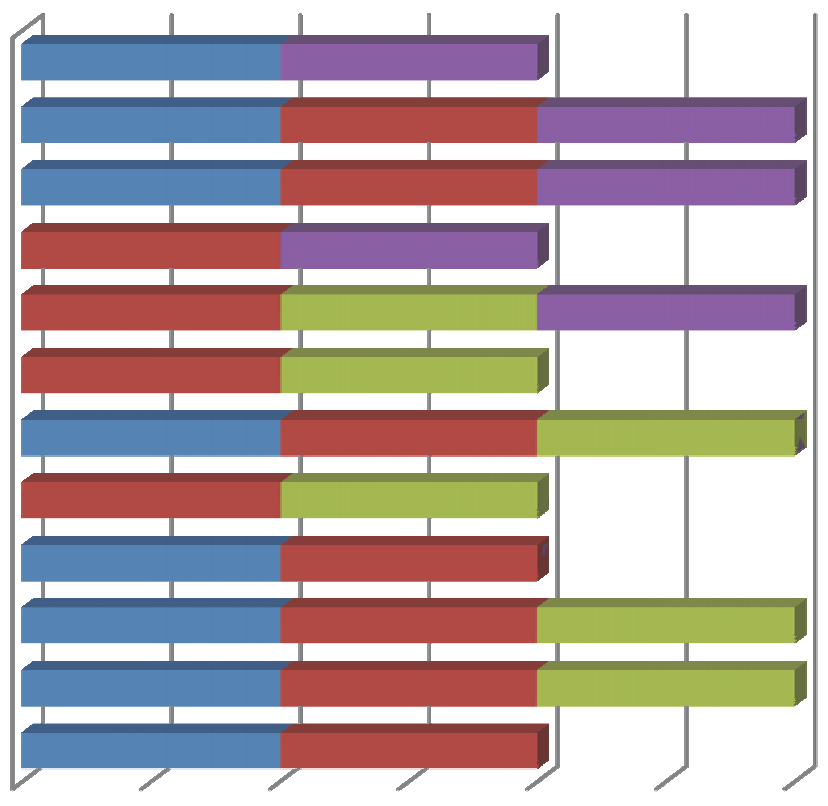

$\square$ The direct management of climate change

- The controll of the rareness level

Ensuring of the right physical and biological environment

- Adaptation of geographic limits

Fig. 7. The protection of plants species from I sensitivity group according to typical factors 
to these categories, management and protection measures of different intensity can be applied to those species (Fig. 8).

The institutional management of species protection during the climate change might be of three levels $(\mathrm{A} ; \mathrm{B} ; \mathrm{C})$. It should depend on categories of species sensitivity to climate change, defined in this article. Level A protection should be applied to plant species of III category of sensitivity (Table 4). The intensity of level A protection is "passive" towards the management of climate change. We suggest no additional protection measures should be applied to it, and the level of

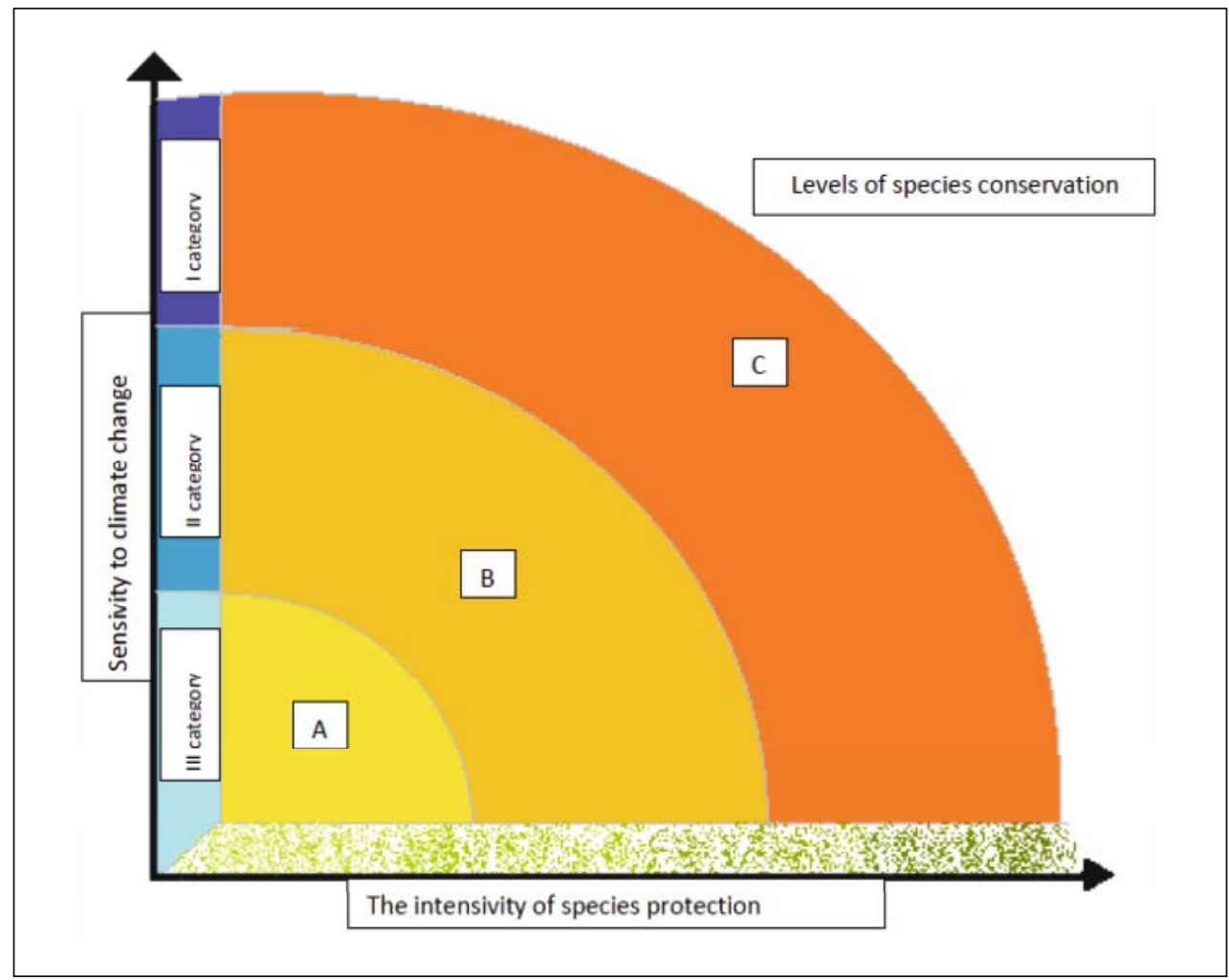

Fig. 8. Levels of species protection reflecting the relation between specie sensitivity and protection intensity

Table 4. Assignation of species protected in Lithuanian reserves to categories of sensitivity to climate change

\begin{tabular}{|c|c|}
\hline $\begin{array}{l}\text { Category } \\
\text { of sensitivity } \\
\text { to climate change }\end{array}$ & Plant species assigned to the category \\
\hline $\begin{array}{l}\text { I category (sensivity } \\
\text { score from }-7 \text { to }-3 \text { ) }\end{array}$ & $\begin{array}{l}\text { Pedicularis sceptrum-carolinum L., Carex magellanica Lam., Juncus stygius L., Listera cordata (L.) } \\
\text { R. Br., Dactylorhiza traunsteineri (Saut.) Soó., Pulsatilla patens (L.) Mill., Dianthus arenarius L., Silene } \\
\text { chlorantha (Willd.) Ehrh., Betula humilis Schrank, Tragopogon gorskianus Rchb. f., Silene lithuanica } \\
\text { Zapał., Dactylorhiza longifolia (Neuman) Aver. }\end{array}$ \\
\hline $\begin{array}{l}\text { Il category (sensivity } \\
\text { score from }-2 \text { to }+2 \text { ) }\end{array}$ & $\begin{array}{l}\text { Lycopodiella inundata L., Carex davalliana Sm., Epipogium aphyllum Sw., Betula nana L., Salix } \\
\text { lapponum L., Orchis militaris L., Cypripedium calceolus L., Hammarbya paludosa (L.) Kuntze., } \\
\text { Trichophorum cespitosum (L.) C. Hartm, Eriophorum gracile W. D. J. Koch ex Roth, Sesleria caerulea } \\
\text { (L.) Ard., Thesium ebracteatum Hayne, Iris sibirica L., Liparis loeselii (L.) Rich, Saxifraga hirculus L., } \\
\text { Salix myrtilloides (L.), Carex buxbaumii Wahlenb., Pilosella echioides (Lumn.) F. W. Schultz et Sch. Bip., } \\
\text { Glyceria nemoralis (R. Uechtr.) R. Uechtr. et Körn., Botrychium matricariifolium A. Br. ex Koch. }\end{array}$ \\
\hline $\begin{array}{l}\text { III category } \\
(\text { sensivity score } \\
\text { from }+3 \text { to }+9)\end{array}$ & $\begin{array}{l}\text { Huperzia selago L., Salix repens L., Drosera intermedia Hayne., Gentiana pneumonanthe L., } \\
\text { Cephalanthera rubra L., Hedera helix L., Pedicularis sylvatica L., Primula farinosa L., Gentianella amarella } \\
\text { L. Börner, Polemonium caeruleum L., Pinguicula vulgaris L., Cirsium heterophyllum (L.) Hill, Centaurea } \\
\text { phrygia L., Dactylorhiza maculata (L.) Soó., Orchis morio L., Orchis mascula (L.) L., Corallorhiza trifida } \\
\text { Chatel., Gymnadenia conopsea (L.) R. Br., Prunella grandiflora (L.) Scholler, Arnica montana L., Epipactis } \\
\text { atrorubens (Hoffm.) Besser, Gladiolus imbricatus L., Malaxis monophyllos (L.) Sw., Campanula cervicaria } \\
\text { L., Cardamine bulbifera (L.) Crantz, Agrimonia procera Wallr., Trifolium lupinaster L., Radiola linoides } \\
\text { Roth, Laserpitium prutenicum L., Cnidium dubium (Schkuhr) Thell., Alima lanceolatum With., Dactylorhiza } \\
\text { fuchsii (Druce) Soó., Platanthera chlorantha (Custer) Rchb., Mentha longifolia (L.) Huds., Nymphaea } \\
\text { alba L., Arctium nemorosum Lej., Dactylorhiza incarnata (L.) Soó., Peplis portula L., Cyperus fuscus L., } \\
\text { Botrychium virginianum (L.) Sw., Botrychium multifidum (G. G. Gmel.) Rupr. }\end{array}$ \\
\hline
\end{tabular}


monitoring could be local in different territories of reserves. A part of plants belonging to this group (34\%) will be superior because of direct effect of climate change and more suitable conditions to spread. Due to this, protection and the budget for management could decrease in the future.

The protection of level B should be applied to plant species of II category (Table 4). These plants belong to group of average sensitivity to climate change. Only some limiting factors that should be managed additionally are relevant to them. However, according to specifics of every plant protection measures should be applied at national level. Even though plenty of them should stay the same due to climate change factors, slight deterioration or improvement might occur.

The protection of level $\mathrm{C}$ would be applied to plant species of I category (most sensitive) (Table 4). Most negative effect of climate change is predicted to these plants. Their protection needs not only additional measures (Table 3 ), but also the most intensive level applied. For plants of I category protection measures of national (level B) and regional (European) level should be applied.

\section{Discussions}

Some general conclusions could be made that negatively sensitive to climate change are $16 \%$ of all rare species in Lithuania strict nature reserves. In Viešvile reserve there are $27 \%$ this group plant species - most of all reserves. The most negatively sensitive to climate change are: Silene chlorantha (Willd.) Ehrh.; Juncus stygius L.; Pulsatilla patens (L.) Mill.; Listera cordata (L.) Tragopogon gorskianus Rchb. f.; Silene lithuanica Zapał.; and Dactylorhiza longifolia (Neuman) Aver. For example, wide study was carried out in Europe and evaluated 1200 protected plant species (Araujo et al. 2004). Similarly, it was discovered that $6-11 \%$ of species will extinct from conservational area in the next 50 years. So, the mentioned species could be nearest to this threat.

Limiting factors, which would lead species to the risk the most, are: bad condition of species in Lithuania (endemic for $42 \%$ species), bad wide-spread in distribution area (43\%), high sensitivity to hydrological regime changes (39\%). Research in Europe testifies that nowadays most of rare species are represented well in protected areas (2002 data). However, $6 \%$ of these 1200 species will not be found in protected areas anymore until 2050 (Araujo et al. 2004). 12\% of our study species are found near the Southern species distribution area boundary, or this area is comparably small. There is a clear risk that due to the climate change these 9 species will not be found in contemporary reserve territory. The aim of species representativeness is one of the main measures evaluating the ability of protected areas to manage consequences of climate change effectively (Hannah et al. 2007). We would recommend considering that future system of protected territories in Lithuania could be created from the existing and new protected territories, so that the region could be able to represent all biodiversity species assigned to it.

Also this study suggests some different management measures for protection of rare plants in the future. Mitigation of the direct effect of climate change should be applied for 14 plant species; improvement of an existing level of rareness - even for 42; respecting the relation to physical and biological environment - for 12 , consideration of spread and geographical limits - for 7 plant species. Other studies show that additional unnatural stress, usually caused by human activity (degradation of habitats and their destruction, overusing of resources, pollution and invasive species) reduces the ability of ecosystems and populations to survive and adapt to the effects of climate change (Hansen et al. 2009). Conservation plans with one of the aim being to manage the effect of climate change has certain tasks such as: saving climatic refugia (refuge place where climate has changed least); to create corridors and nets in which species would migrate due to changing conditions; to save population consolidation zones ensuring gene transfer; revive communities, such as forests which mitigate the effect of climate change; to save more residential populations; to conserve heterogeneity of habitats (Millar et al. 2007).

According to species sensitivity, three management intensity levels were suggested in this research. A lot of studies determine different management measures in climate change. In some ecosystems the impact of changing climate should be avoided or mitigated while in others, where it is hard to avoid the impact, new ecosystems should be created. The management measures are called "Climate Change-integrated Conservation Strategies (CCS)" (Hannah et al. 2000). According to Dawson (2011) model, such characteristics as adaptive capacity, sensitivity and vulnerability should determine the intensity of the management program. Species with low adaptive ability, the highest vulnerability and sensitivity need the most intensive protection measures (such as conservation ex-situ and revival) (Dawson et al., 2011). Our study suggests the management system of three intensity levels. The first one (A) is for positively affected species of climate change. Another (B) - for neutral sensitive ones. Equal measures could be applied not in separate reserves, but in all natural protected territories where those species are found despite the conditions of populations existing there. Monitoring of all populations should be carried out. The last one (C) for species negatively affected by climate change. For their protection an active regional cooperation as well as sharing of resources and knowledge are needed. Reserves could use global protection measures, based on the experience of other countries. Monitoring would be applied to all populations in their distribution area. The shift of species extension area should be modeled in Europe. During the investigation new territories beyond northern border should be established. Countries that belong to new areas should take over the protection of rare plants; among them is Lithuania which should protect new species in Lithuania if they are rare in Europe and in all areas of distribution.

During the research ecological factors limiting plant species in the perspective of climate change were identified. Another important predicted effect of climate change is growth and widespread of plant parasites when the temperature is rising. Plants do not have equal vulnerability to diseases and parasites, therefore species that are unattractive to parasites have advantage (Sturrok et al. 2011). In further research it is suggested to gather information on possible attacks of parasites and diseases against rare plants and possible prevention measures. Also early phenological phenomena and their effect on ecosystems of rare plants should be evaluated (Kalvane et al. 2009). In the research we also assessed how other plants of the community can affect the condition of species; the competition of rare plants; dependency on exact vegetable composition, tolerance of shadow and shade. However, the facts how 
animals, field organisms and other parts of ecosystem affect plants were not evaluated (Gilman et. al. 2010). Therefore, a deeper investigation of these factors with regard to protected plants in reserves is needed.

\section{References}

Ackerly, D.D., Loarie S.R., Cornwell, W.K., Weiss, S.B., Hamilton, H., Branciforte, R. \& Kraft, N.J.B. (2010). The geography of climate change: implications for conservation biogeography, Diversity and Distributions, 16, pp. 476-487.

Araujo, M.B., Cabeza, M., Thuiller, W., Hannah, L. \& Williams, P.H. (2004). Would climate change drive species out of reserves? An assessment of existing reserve selection methods, Global Change Biology, 10, pp. 1618-1626.

Barber, Ch.V., Miller, K.R. \& Boness, M. (2004). Securing protected areas in the face of global change, issues and strategies. IUCN, Gland, Switzerland, and Cambridge, UK. P. 234.

Bell, G. \& Gonzalez, A. (2009). Evolutionary rescue can prevent extinction following environmental change, Ecology Letters, 12, pp. 942-948.

Bellard, C., Bertelsmeier, C., Leadley, P., Thuiller, W. \& Courchamp, F. (2012). Impacts of climate change on the future of biodiversity, Ecology Letters, 15, pp. 365-377.

Bertin, R.I. (2008). Plant phenology and distribution in relation to recent climate change, The Journal of the Torrey Botanical Society, 135 (1), pp. 126-146.

Brook, B.W., Akcakaya, H.R., Keith, D.A., Mace, G.M., Pearson, R.G. \& Araujo, M.B. (2009). Integrating bioclimate with population models to improve forecasts of species extinctions under climate change, Biology Letters, 5, pp. 723-725.

Bukantis, A. \& Rimkus, E. (2005). Climate variability and change in Lithuania, Acta Zoologica Lituanica, 15(2), pp. 100-104.

Bukantis, A., Ignatavičius, G., Satkūnas, J., Sinkevičius, S., Šulijienè, G., Vasarevičius, S. \& Veteikis, D. (2013). Lithuania's environment: state, processes and trends. Vilnius: Aplinkos apsaugos agentūra, pp. 216.

Campbell, A., Kapos, V., Scharlemann, J.P.W., Bubb, P., Chenery, A., Coad, L., Dickson, B., Doswald, N., Khan, M.S.I., Kershaw, F. \& Rashid, M. (2009). Review of the literature on the links between biodiversity and Climate Change: impacts, adaptation and mitigation. Secretariat of the Convention on Biological Diversity, Montreal, Technical Series (No. 42), pp. 124.

Chambers, L.E., Hughes, L. \& Weston, M.A. (2005). Climate change and its impact on Australia's avifauna, Emu, 105, pp. 1-20.

Conroy, M.J., Michael, C.R., Nichols, J.D., Stodola, K.W. \& Cooper, R.J. (2011). Conservation in the face of climate change: The roles of alternative models, monitoring, and adaptation in confronting and reducing uncertainty, Biological Conservation, 144, pp. 1204-1213.

Davis, M.B. \& Shaw, R.G. (2001). Range shifts and adaptive responses to Quaternary climate change, Science, 292, pp. 673-679.

Dawson, T.P., Jackson, S.T., House, J.I., Prentice I.C. \& Mace, G.M. (2011). Beyond predictions: biodiversity conservation in a changing climate, Science, 332, pp. 53-58.

Elith, J. \& Leathwick, J.R. (2009). Species distribution models: ecological explanation and prediction across space and time, Annual Review of Ecology Evolution and Systematics, 40, pp. 677-697.

Gečaite, I. \& Rimkus, E. (2010). Snow cover regime in Lithuania, Geografija, 46(1), pp. 17-24. (In Lithuanian)

Gilman, S.E., Urban, M.C., Tewksbury, J., Gilchrist G.W. \& Holt, R.D. (2010). A framework for community interactions under climate change, Trends of Ecology Evolution, 25, pp. 325-331.

Hannah, L., Midgley, G., Andelman, S., Araujo, M., Hughes, G., Martinez-Meyer, E., Pearson, R. \& Williams, P. (2007). Protected area needs in a changing climate, Frontiers in Ecology and the Environment, 5 (3), pp. 131-138.

Hannah, L., Midgley, G.F., Lovejoy, T., Bond, W.J., Bush, M., Lovett, J.C., Scott, D. \& Woodward, F.I. (2000). Conservation of biodiversity in a changing climate, Conservation Biology, 16 (1), pp. 264-268.

Hannah, L., Midgley, G.F. \& Millar, D. (2002). Climate change-integrated conservation strategies, Global Ecology and Biogeography, 11, pp. 485-495.

Hansen, L., Hoffman, J., Drews, C. \& Mielbrecht, E. (2009). Designing Climate-Smart Conservation: guidance and case studies, Conservation Biology, 24 (1), pp. 63-69.

Hartig, E.K., Grozev, O. \& Rosenzweig, C. (1997). Climate change, agriculture and wetlands in Eastern Europe: vulnerability, adaptation and policy, Climatic Change, 36, pp. 107-121.

Heller, N.E. \& Zavaleta, E.S. (2009). Biodiversity management in the face of climate change: A review of 22 years of recommendations, Biological Conservation, 142, pp. 14-32.

IPCC (2013). Climate Change 2013: The Physical Science Basis. Working Group I Contribution to the IPCC 5th Assessment Report. IPCC, Switzerland 2013.

Kalvane, G., Romanovskaja, D., Briede, A. \& Baksiene, E. (2009). Influence of climate change on phenological phases in Latvia and Lithuania, Climate Research, 39, pp. 209-219.

Lavergne, S., Mouquet, N., Thuiller, W. \& Ronce, O. (2010). Biodiversity and climate change: integrating evolutionary and ecological responses of species and communities, The Annual Reviews of Ecology, Evolution and Systematics, 41, pp. 321-350.

Lawler, J.J. (2009). Climate change adaptation strategies for resource management and conservation planning, The Year in Ecology and Conservation Biology, 1162, pp. 79-98.

Loarie, S.R., Duffy, P.B., Hamiltons, H., Asner, G.P., Field, Ch.B. \& Ackerly, D.D. (2009). The velocity of climate change. Nature, 462, pp. 1052-1055.

Lovejoy, T.E., Hannah, L. (2005). Climate Change and Biodiversity, Yale university press, New Haven 2005.

Mawdsley, J.R., O'malley, R. \& Ojima, D.S. (2009). A review of climate-change adaptation strategies for wildlife management and biodiversity conservation, Conservation Biology, 23 (5), pp. 1080-1089.

McMahon, S.M., Harrison, S.P., Armbruster, W.S., Bartlein, P.J., Beale, C.M., Edwards, M.E., Kattge, J., Midgley, G., Morin, X. \& Prentice, I.C. (2011). Improving assessment and modeling of climate change impacts on global terrestrial biodiversity, Trends in Ecology and Evolution, 26 (5), pp. 249-259.

Midgley, G.F, Hannah, L, Millar, D., Rutherford, M.C. \& Powrie, L.W. (2002). Assessing the vulnerability of species richness to anthropogenic climate change in a biodiversity hotspot, Global Ecology and Biogeography, 11, pp. 445-51.

Millar, C.I., Stephenson, N.L. \& Stephens, S.L. (2007). Climate change and forests of the future: managing in the face of uncertainty, Ecological Applications, 17, pp. 2145-2151.

Noss, R.F. (2001). Beyond Kyoto: forest management in a time of rapid climate change, Conservation Biology, 15, pp. 578-590.

Ozolinčius, R., Lekevičius, E., Stakènas, V., Galvonaite, A., Samas, A. \& Valiukas, D. (2014). Lithuanian forests and climate change: possible effects on tree species composition, European Journal of Forest Research, 133 (1), pp. 51-60.

Opdam, P. \& Wascher, D. (2004). Climate change meets habitat fragmentation: linking landscape and biogeographical scale levels in research and conservation, Biological Conservation, 117, pp. 285-297.

Pearson, R.G. \& Dawson, T.P. (2005). Long-distance plant dispersal and habitat fragmentation: identifying conservation targets for spatial landscape planning under climate change, Biological Conservation, 123, pp. 389-401. 
Rice, K.J. \& Emery, N.C. (2003). Managing microevolution: restoration in the face of global change, Frontiers in Ecology and the Environment, 1, pp. 469-478.

Pyke, C.R. \& Fischer, D.T. (2005). Selection of bioclimatically representative biological reserve systems under climate change, Biological Conservation, 121, pp. 429-441.

Povilaitis, V., Lazauskas, S. \& Kriščiukaitienè, I. (2009). Simulations of cereal yield by presumptive of climate change scenarios in Lithuania, Agricultural Science, 16, pp. 224-229. (In Lithuanian)

Scott, D., Malcom, J. \& Lemieux, C.J. (2002). Climate change and biome representation in Canada's National Park system: implications for system planning and park mandates, Global Ecology and Biogeography, 11, pp. 475-484.

Shafer, C.L. (1999). National park and reserve planning to protect biological diversity: some basic elements, Landscape and Urban Planning, 44, pp. 123-153.
Skov, F. \& Svenning, J.C. (2004). Potential impact of climatic change on the distribution of forest herbs in Europe, Ecography, 27, pp. 366-380.

Soto, C.G. (2001). The potential impacts of global climate change on marine protected areas, Reviews in Fish Biology and Fisheries, 11, pp. 181-195

Taminskas, J., Linkeviciene, R., Mazeika, J. \& Kibirkstis, G. (2008). Climate change impact on Cepkeliai marsh hydro-meteorological conditions: vertical water cycle characteristics, Annales Geographicae, 40, pp. 50-60. (In Lithuanian)

Walther, G.R. (2010). Community and ecosystem responses to recent climate change, Philosophical Transactions of the Royal Society B-Biological Sciences, 365, pp. 2019-2024.

Welch, D. (2005). What should protected area managers do in the face of climate change? The George Wright Forum, 22, pp. 75-93.

Williams, J.E. (2000). The biodiversity crisis and adaptation to climate change: a case study from Australia's forests, Environmental Monitoring and Assessment, 61, pp. 65-74. 